Available online on 15.1.2020 at http://ujpr.org
Universal Journal of Pharmaceutical Research
An International Peer Reviewed Journal
Open access to Pharmaceutical research

\title{
BACTERIAL CONTAMINATION OF DIALYSIS WATER AND DIALYSATE ATMUKALLA ARTIFICIAL KIDNEY CENTER IN MUKALLA CITY - HADHRAMAUT-YEMEN: RATE OF CONTAMINATION AND SENSITIVITY OF BACTERIAL ISOLATES TO ANTIBIOTICS

\author{
Wedad M Al-Haik ${ }^{1}$ (D), Ahmed M Al-Haddad ${ }^{2}$, , Saba O Bekeir ${ }^{1,2}{ }^{(D}$, Hassan A Al-Shamahy ${ }^{3}$ \\ ${ }^{I}$ Department of Biology, Faculty of Science, Hadhramout University, Al-Mukalla, Yemen. \\ ${ }^{2}$ Department of Medical Laboratories, College of Medicine and Health Sciences, Hadhramout University, Al-Mukalla, Yemen. \\ ${ }^{3}$ Department of Microbiology, Faculty of Medicine and Health Sciences, Sana'a University, Sana'a, Yemen.
}

\section{ABSTRACT}

Objective: Water treatment systems are a vital factor in dialysis therapy and precise control of hemodialysis water bacteriological quality is predominantly important in order to assurance a better quality of life of the hemodialysis patients. The purpose of this study was to detect the level of contamination in hemodialysis water and dialysate by bacteria in Mukalla Artificial Kidney Center and investigate the antimicrobial resistance patterns of isolated bacteria.

Methods: Forty eight samples of water and dialysate were assembled weekly over a period of 3 months from 4 points. Bacteriological analysis of samples was carried out then antimicrobial susceptibilities patterns of isolated bacteria were concluded by disk diffusion method.

Results: The mean of total count of bacteria for dialysis water and dialysate were higher than the recommended values (100 CFU/ $\mathrm{ml}$ ). The isolated bacteria which colonized the hemodialysis systems were mostly Gram-negative bacilli as Pseudomonas sp., Serratia sp., Citrobacter sp. and Enterobater sp. In general, most of the isolated bacteria were poorly responsive to antibiotics.

Conclusion: In conclusion: Dialysis water and dialysate not passed to meet the bacteriological provisions for hemodialysis. To reduce the hazard of contaminants for hemodialysis patients, a sufficient system for water treatment, disinfection of hemodialysis system, and bacteriological contamination monitoring of the water and dialysate are necessary.

Keywords: Bacterial contamination, dialysis water, dialysate, hemodialysis, Yemen.

Article Info: Received 2 November 2019; Revised 11 December 2019; Accepted 1 January, Available online 15 January 2020 Cite this article-

口f Al-Haik WM, Al-Haddad AM, Bekeir SO, Al-Shamahy HA. Bacterial contamination of dialysis water and dialysate at Mukalla artificial kidney center in Mukalla city-Hadhramaut-Yemen: rate of contamination and sensitivity of bacterial isolates to antibiotics. Universal Journal of Pharmaceutical Research 2019; 4(6): 64-68.

DOI: https://doi.org/10.22270/ujpr.v4i6.339

Dr. Wedad M. Al-Haik, Department of Biology

773239584, E-mail: wedmicro2016@gmail.com

\section{INTRODUCTION}

Hemodialysis patients endure from abnormalities of immune system as directly result of uremia and its metabolic consequences; cause them more vulnerable to infections. Such defects include impairment of the action of neutrophils, lymphocytes $\mathrm{B}$ and $\mathrm{T}$ and monocytes, causing defective antigen processing, antibody production and cell mediated immune response and thus to an increased incidence of microbial infections ${ }^{1}$. These infections are the second leading cause of death among HD patients, with an attributed mortality rate of $14 \%{ }^{2,3}$. The morbidity and mortality of patients with ESRD are serious problems in Yemen as in the world ${ }^{4}$. In addition, hemodialysis is the most common method of renal replacement therapy for patients with either acute renal injury in the failure stage or end stage renal failure. Hemodialysis is the process of removing toxins directly from the blood using diffusion across a semi permeable membrane ${ }^{5}$. Removing the harmful wastes and extra salt and fluids helps control the blood pressure and keep the proper balance of electrolytes ${ }^{6}$. Each patient using HD machine is exposed to large volume of water $(400 \mathrm{~L}$ per week) used for production of dialysate, from which, if it is not properly treated, all the low molecular weight substances present in water as chemical, bacterial and toxic contaminants have direct access through the semi permeable membrane of dialyzer to HD patient's blood stream ${ }^{7,9,10}$. To prevent patients from risks of water contaminants there is a number of standards for quality of dialysis water and dialysate have been proposed ${ }^{11}$. There are a number of regional and national guidelines with regard to maximally conventional limits of bacterial 
contamination of dialysis water. The American Association of Medical instrumentation (AAMI) advises the highest acceptable levels of viable bacteria count to be 200 colony forming units (CFU) per milliliter of water and endotoxin concentrates of $<2$ $\mathrm{IU} / \mathrm{ml}$, while European Pharmacopoeia (Ph. Eur.) maximum value is $100 \mathrm{CFU} / \mathrm{ml}$ and endotoxin concentrates of $<0.25 \mathrm{IU} / \mathrm{ml}^{5,12,13}$.

However, no data are available regarding bacterial contamination in the Hadramout dialysis water distribution systems. Therefore, it is important to explore the possibility of contamination of dialysis water circulation systems in the dialysis center in Hadramout. In addition to that, this study was specially carried out to detect level of bacterial contamination and bacteriological quality of hemodialysis water and dialysate in Mukalla Artificial Kidney Center (MKC) in Mukallahcity, Hadhramout, Yemen.

\section{METHODS}

The samples were collected from MKC in Ibn Sena General Hospital in Hadhramout. The center consists of four rooms and having about $18 \mathrm{HD}$ machines and performs approximately 1305 hemodialysis sessions monthly in three shifts a day. The water samples were collected weekly over a period of 3 months from four measurement points (sampling were repeated from the same points each month). The measurement points were:

1. Municipal water.

2. Return line of reverse osmosis loop.

3. Water prior to the machine.

4. Dialysate solution.

The samples had been collected in clean sterilized glass bottles of $250 \mathrm{ml}$ capacity. These bottles were autoclaved before sampling at $121^{\circ} \mathrm{C}$ temperature for 15 minutes. At each point of collection the valve was disinfected by heat and using $70 \%$ isopropanol, then opened and water was allowed to flow for a minimum of 2 minutes at normal pressure and flow rate before the samples was drawn ${ }^{13,14,15}$. Samples were then processed at Dar Alshifa Medical Specialized Center Laboratory.

\section{Total enumeration of bacteria}

The determination of total bacteria count in water samples was done by using pour plate method. Serial dilutions of water samples were made with peptone water and inoculated on to plate count agar. Plates were incubated at $37^{\circ} \mathrm{C}$ for 24 to 48 hours. The plates selected for counting were that producing 30-300 $\mathrm{CFU} / \mathrm{ml}$ with some modulations ${ }^{5}$.

\section{Test for total coliform bacteria}

The total bacteria were determined by utilizing the most probable number (MPN) method. Aliquotsof 10 , $1 \mathrm{ml}$ and $0.1 \mathrm{ml}$ of water samples and dialysate were collected from the four points mentioned earlier were added to tubes containing MacConkey broth. Test tubes were incubated at $37^{\circ} \mathrm{C}$ for 48 hours. After incubation, the production of acid and gas formation was considered positive. Number of the positive tubes was recorded and MPN was calculated according to MPN tables Positive tubes were selected for the confirmed test procedures to detect the indicator bacteria of fecal origin E. coli. EMB media was being used $^{\mathbf{1 6}}$. The tubes that only showed turbidity were placed on MacConky agar, blood agar and nutrient agar to be tested for non-fermentivebacteria ${ }^{17}$.

Identification and characterization of isolating bacteria

The bacteria were isolated from developing colonies in the plate count agar as well as from MacConky broth were submitted to Gram stain and set of biochemical tests including the following: citrate test, urease test, kligler iron agar (KIA), oxidase test, catalease test, sulfide-indole - motility test (SIM) and coagulase test.

\section{Antimicrobial resistance}

Antibiotic sensitivities were done by using disk diffusion method on the Mueller-Hinton agar (KirbyBauer method) ${ }^{18}$. The antibiotic discs under study were: ceftazidime (CAZ $30 \mathrm{mcg}$ ), cefepime (CPM 30 $\mathrm{mcg}$ ), ciprofloxacin (CIP 5mcg), amikacin (AK $30 \mathrm{mcg}$ ), ceftriaxone, (CTR 30mcg), piperacillin (PI $100 \mathrm{mcg}$ ) and trimethoprim (TR $5 \mathrm{mcg}$ ).

\section{RESULTS AND DISCUSSION}

The contamination of dialysis water and dialysate were above the (Ph. Eur.) recommended level: $100 \mathrm{CFU} / \mathrm{ml}$. This indicates that there is a problem of biological contamination during water-treatment processes. In line with studies by Pisani et al. ${ }^{19}$ and Heidarieh et al., ${ }^{10}$ reported that the viable count always exceeded the recommended values.

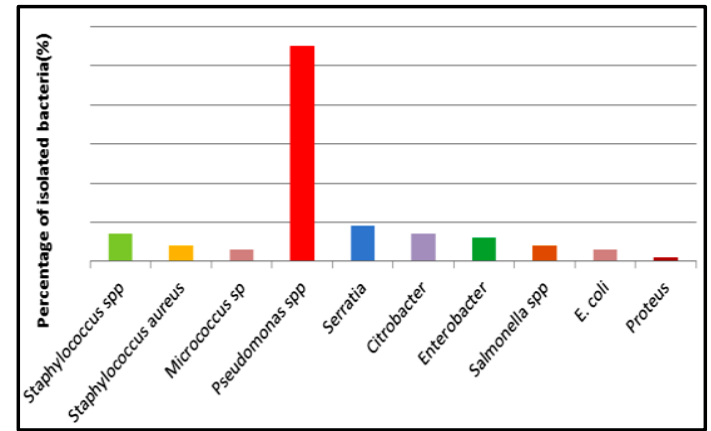

Figure 1: Isolated bacteria fromhemodialysis center.

The maximum total count of bacteria was related tothe back loop $\left(1.816 \times 10^{3} \pm 2615.3 \mathrm{CFU} / \mathrm{ml}\right)$ (Table 1$)$. The minimum number of total bacteria was observed in the prior to machine $\left(1.78 \times 10^{2} \pm 222.1 \mathrm{CFU} / \mathrm{ml}\right)$. These results agreed with a similar study conducted by Oumokhtar et al., ${ }^{7}$ that the maximum total bacterial count was related to back loop. These results have been found in current study suggest that dialysis system and tubing along the fluid pathways within dialysis supplies are the main source of contamination and biofilm development and result in the high levels of the bacterial contamination at different sampling points.

In present study, the maximum total count of coliforms was related to municipal water $(3.41 \pm 3.1 \mathrm{MPN} / 100$ $\mathrm{ml})$. The results refers to the presence of Enterobacteriaceae in water samples, and the contamination level of Enterobacteriaceae in municipal water was more than it in dialysis water and dialysate and there was significant differences between 
them (P-value=0.030). Ninety-eight bacteria were isolated from all water samples in MKC. The water samples were contaminated by both gram-positive and gram-negative bacteria. Gram-negative bacteria $(85.7 \%)$ were the main contaminants of water in MKC, while the gram-positive bacteria represented only $(14.2 \%)$.

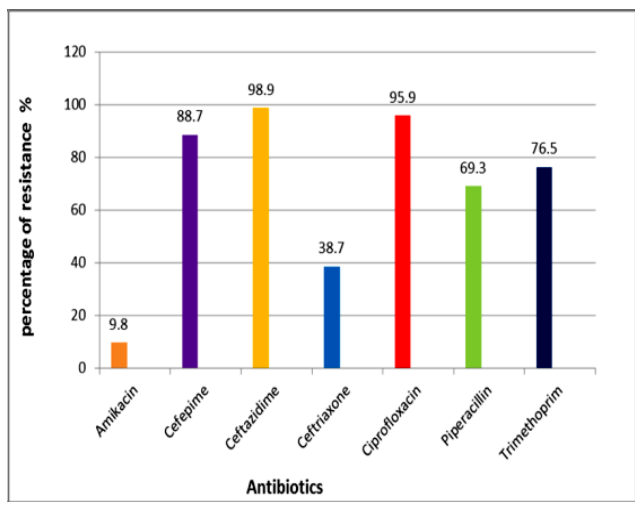

Figure 2: Antibiotic susceptibility of isolatedbacteria in MKC.

This results agreed with Oumokhtar et al., ${ }^{7}$ and Okunola and Olaitan, ${ }^{5}$ who reached that most isolated bacteria were gram- negative bacteria.The maximum number of isolated bacteria was for Pseudomonas sp. (55.1\%), followed by Serratia sp. (9.18\%), Citrobacter sp. $(7.14 \%)$, non-coagulase Staphylococcus sp. (7.14\%), Enterobater sp. (6.12\%), Salmonella sp. (4.08\%), S. aureus (4.08\%) , E.coli (3.06\%), Micrococcus sp. (3.06 \%) and Proteussp. (1.02\%) (Figure 2). The highest percentage of isolated bacteria was from the municipal water $(30.6 \%)$, followed by prior to machine (24.4\%), then dialysate solution $23.4 \%$ and the lowest percentage of isolated bacteria was from Back loop (21.4\%) (Table 2). The most predominant isolated bacteria was Pseudomonas sp. $(55.1 \%)$, this finding was in agreement with other studies conducted by Pisani et al., ${ }^{19}$ and Lima et al., ${ }^{20}$, where the percentage of Pseudomonas sp. was the highest among the isolates. Also Arvanitidou et al., ${ }^{21}$, Borges et al., ${ }^{22}$, Montanari et al., ${ }^{1}$, Oumokhtar et al., ${ }^{7}$ and Okunola and Olaitan, ${ }^{5}$ reported that Pseudomonas sp. was the most prevalent isolated bacteria as following: (27\%), (32.5\%), (44\%), (52.8\%) and $(55 \%)$, respectively. This finding was attributed to that Pseudomonas sp. is recognized to rapidly grow in dialysis fluids and this consequence gives cause for anxiety, in view of the well-known resistance to antibiotics and biocides ${ }^{2,23}$. Results of present study have showed that machine No. 5 was the most polluted among machines. The bacteria isolated from Machine No. 5 were as follows: Pseudomonas sp., Staphylococcus non-coagulase., $\quad S$ a aureus, Micrococcus sp. and Enterobacter sp. This device may be out of date or use more or more polluted. Result of present study suggests that there was a problem with the effectiveness of disinfectant used, also the biofilm development within the dialysis machine led to contamination of the dialysate. The contamination level of the second month was the highest (52.9\%), followed by the third month (33.8\%) and the first month was $(13.2 \%)$, with a statistically significant difference in the level of pollution between the three months (value of $\mathrm{P}$ $=0.432)$. Also, there was a rapid increase in the level of bacteria numbers after the second periodic chemical disinfection of the water treatment system. This result agreed with study conducted by Oumokhtar et al., ${ }^{7}$. The second chemical disinfection of the system has been done in the 2 sd month. Finding of present study suggest that the municipal water contamination rate was high in the $2^{\text {nd }}$ month also the biofilm have been installed in the water treatment system and hemodialysis machines despite the disinfection procedure routinely applied. Three membranes of the RO device were replaced in the third month and therefore it may be expected that this was the reason for decrease bacteria level to $(33.8 \%)$ and thus the reduction of biofilm. Nazemi et al., asserted that after each period of disinfection, there was observed increased contamination, which was due to the bacterial biofilms generated in the water pipes ${ }^{17}$. In addition, Nystrand stated that the occurrence of a biofilm on the pipes directs to a rapid re growth of bacteria after a few hours of disinfection of the water system $^{24}$. The 98 bacterial isolates showed variable resistance patterns. Antibiotic test results showed that a higher resistance was $98.9 \%$ against Ceftazidime (30 $\mathrm{mcg}$ ). Ciprofloxacin (5 mg) and amikacin (30 mg) were the antibiotics that showed the lowest number of resistance isolates, $9.1 \%$ and $1.02 \%$, respectively. In general, most of the isolated bacteria were poorly responsive to antibiotics. The most resistant bacteria were Proteus sp. and E. coli, they showed resistance to all antibiotics except Ciprofloxacin (Figure 3). The random use of antibiotics and transmission of resistant bacteria between patients were the main factors increasing antimicrobial resistance prevalence ${ }^{25}$. This study reached to about $100 \%$ of E.coli were resistant to all antibiotics except Amikacin and Trimethoprim $66.6 \%$ while Ciprofoxacine $0 \%$ (100\% of E. coli were sensitive to Ciprofloxacin). This finding was in line with the work of Romanus et al., finding that $81 \%$ of E. coli were sensitive to Ciprofloxacin, $73 \%$ resistant to Trimethoprim ${ }^{26}$. Also Arvanitidou et al., showed that $0 \%$ of E. coli were resistant to Ciprofloxacin, while $100 \%$ were sensitive to Amikacin, Cefepime and Ceftazidime $^{21}$. This finding was closed to a study by Omoya and Ajayi, finding that $100 \%$ of Proteus sp. showed resistance to Ceftriaxone while $0 \%$ showed resistance to Ciprofloxacin ${ }^{27}$. Also Yah et al., reported that Proteus sp. showed low resistance against Ciprofloxacin $(6.1 \%)^{28}$. Pseudomonas sp. showed the resistance to Amikacin (9.2\%), Cefepime (83.3\%), Ceftazidime (98.1\%), Ceftriaxone (16.6\%), Ciprofloxacin (1.8\%), Piperacillin (46.2\%) and Trimethoprim $(70.3 \%)$. This finding was closed to what Romanus et al. reached, that Pseudomonas sp. were sensitive to Ciprofloxacin and Amikacin as $83 \%$, $100 \%$ respectively ${ }^{26}$. Borges et al., also found that Pseudomonas sp. was sensitive to Amikacin and Ciprofloxacin as $64 \%$ and $77 \%$ respectively ${ }^{22}$. A study conducted by Khan et al., reported that $80 \%$ of Pseudomonas sp. was resistant against Ceftazidime ${ }^{29}$. 
Table 1: Mean values of total bacteria in treated water and dialysate.

\begin{tabular}{crccc}
\hline & & Total count of bacteria CFU/ml & \multicolumn{1}{c}{$\boldsymbol{P}$ value } \\
\hline Sampling points & Back loop & Prior to machine & Dialysate & \multirow{2}{*}{0.023} \\
\hline Mean values \pm SD & $1.816 \times 10^{3} \pm 2615.3$ & $1.78 \times 10^{2} \pm 222.1$ & $1.835 \times 10^{2} \pm 267.6$ & \\
\hline
\end{tabular}

SD: standard deviation, $P$ value: $\leq 0.05$

Table 2: Bacteria isolated from the four points and their percentage at each point.

\begin{tabular}{lccccc}
\hline Isolated bacteria & \multicolumn{5}{c}{ No. $(\%)$} \\
\cline { 2 - 6 } & $\begin{array}{c}\text { Municipal } \\
\text { water }\end{array}$ & Back loop & $\begin{array}{c}\text { Prior to } \\
\text { machine }\end{array}$ & $\begin{array}{c}\text { Municipal } \\
\text { water }\end{array}$ & $\begin{array}{c}\text { Back } \\
\text { loop }\end{array}$ \\
\hline Pseudomonas sp. & $11(11.2 \%)$ & $14(14.2 \%)$ & $16(16.3 \%)$ & $13(13.2 \%)$ & 54 \\
\hline Proteus sp. & 0 & $1(1.02 \%)$ & 0 & 0 & 1 \\
\hline Salmonella sp. & $1(1.02 \%)$ & $1(1.02 \%)$ & 0 & $2(2.04 \%)$ & 4 \\
\hline $\begin{array}{l}\text { Non-coagulase } \\
\text { Staphylococcus } \text { sp. }\end{array}$ & $3(3.06 \%)$ & $1(1.02 \%)$ & $2(2.04 \%)$ & $1(1.02 \%)$ & 7 \\
\hline S. aureus & 0 & $1(1.02 \%)$ & $2(2.04 \%)$ & $1(1.02 \%)$ & 4 \\
\hline Micrococcus sp. & 0 & $1(1.02 \%)$ & 0 & $2(2.04 \%)$ & 3 \\
\hline Citrobacter sp. & $5(5.10 \%)$ & 0 & $2(2.04 \%)$ & 0 & 7 \\
\hline Enterobacter sp. & $3(3.06 \%)$ & $1(1.02 \%)$ & 0 & $2(2.04 \%)$ & 6 \\
\hline E.coli & $3(3.06 \%)$ & 0 & 0 & 0 & 3 \\
\hline Serratia sp. & $4(4.08 \%)$ & $1(1.02 \%)$ & $2(2.04 \%)$ & $2(2.04 \%)$ & 9 \\
\hline $\begin{array}{l}\text { Total } \\
(\%)\end{array}$ & 30 & 21 & 24 & 23 & 98 \\
\hline$P$ - value & $(30.6 \%)$ & $(21.4 \%)$ & $(24.4 \%)$ & $(23.4 \%)$ & \\
\hline & \multicolumn{5}{c}{0.96} \\
\hline
\end{tabular}

\section{CONCLUSION}

Hemodialysis water distribution systems in MKC were colonized with both gram negative and gram positive bacteria, which display multi-resistance to antibiotics. The CFU values for dialysis water and dialysate exceeded the limit of $100 \mathrm{CFU} / \mathrm{ml}$. Therefore, an adequate water-treatment system, the efficient disinfection of haemodialysis equipment and dialyzers, and the microbiological monitoring of water and dialysate are key points in maintaining the quality of the renal replacement therapy service offered to patients with chronic renal disease.

\section{AUTHOR'S CONTRIBUTION}

The manuscript was carried out, written, and approved in collaboration with all authors.

\section{ACKNOWLEDGEMENT}

Thank you very much to the Dar Al Shifa Specialist Medical Center and Al Mukalla Al Sheriani Center at Ibn Sina General Hospital in Hadhramaut.

\section{CONFLICTS OF INTEREST}

There are no any conflicts of interest.

\section{REFERENCES}

1. Montanari L, Sartori F, Cardoso M, Varo S, et al. Microbiological contamination of a hemodialysis center water distribution system. J Inst Trop Med São Paul 2009; 51(1):37-43.

2. Jaber B. Bacterial infections in hemodialysis patients: pathogenesis and prevention.Kidney Int 2005; 67: 25082519.https://doi.org/10.1111/j.1523-1755.2005.00364.x

3. Quori A, Baamonde-Labroda E, Garcia-Canton C, et al. Surveillance for infections and other adverse events in dialysis patients in southern Gran Canaria. Revista Nefrologia 2011; 31(4): 457- 463.

4. Rodriguez J, Crespo R. Study of chronic renal failure in Miltary hospital Sana'a. Yemen. Elect Bil J 2008; 2: 27.
5. Okunola O, Olaitan J. Bacterial contamination of hemodialysis water in three randomly selected centers in South Western Nigeria. The Nigerian J Clin Pract 2016; 19: 491-495 .https://doi.org/10.4103/1119-3077.183293

6. Ibrahim M, Ahmed H, Magbool, F. Quality control of the fluids utilized in dialysis with the study of the hemodialysis status in Khartoum State. Int Res J Pharmacy Med Sci 2019; 2(2): $1-5$.

7. Oumokhtar B, Lalami A, Mohmoud M, Berrada S, Arrayhani M, Houssaini T. Prevent infection linked to the dialysis water in a hemodialysis center in Fez city (Morocco). Pan African Med J 2013; 16:122- 126. https://doi.org/10.11604/pamj.2013.16.122.2877

8. Asserraji, M, Maoujoud A, Belarbi M, Elfarouki R. Monitoring the microbiological quantity of dialysate and treated water. Saudi J Kid Dis Transpl 2014; 25(1): 91-95. PMC4017163

9. Manjunath V, Chandrakanth C, Amaranath S, Rangarajan D, Anushree C. Outbreak of Burkholderiacepacia bacteremia in a hemodialysis unit. Med Innovat 2014; 3(2):33- 35. https://doi.org/10.1053/ajkd.2000.8295

10. Heidarieh P, Shaharaki A, Yaghoubfar R, Hajehasani A, Mirsaeidi A. Microbiological analysis of hemodialysis developing country. American Soc Art Int Org 2016; 62(3): 332- 339.https://doi.org/10.1097/MAT.0000000000000353

11. Shahryari A, Nikaeen M, Hatamzadeh M, Dastjerd M, Hassanzadeh A. Evaluation of bacteriological and chemical quality of dialysis water and fluid in Isfahan, Central Iran. Iran J public health 2016; 45(5): 650-656. PMID: 27398338

12. Pontoriero G, Pozzon P, Andrulli S, Locatelli F. The quality of dialysis water. Nephro Dial Transplant 2003;18(7):21-25. https://doi.org/10.1111/sdi.12113

13. Glorieux G, Neirynck N, Veys N, Vanholder R. Daialysis water and fluid purity: more than endotoxin. Nephro Dial Transp 2012; 27: 4010-4021. https://doi.org/10.1093/ndt/gfs306

14. Gorke A, Kittel J. Routine disinfection of the total dialysis fluid systems. EDTNA-ERCA J 2002; 28(3): 130-133. https://doi.org/10.1111/j.1755-6686.2002.tb00226.x

15. Verma S, Indumathi V, Gurudev K, Naik S. Bacteriological quality of treaded water and dialysate in hemodialysis unit of a Tertiary Care Hospital. J Clin Diag Res 2005; 9(10):14-16. https://doi.org/10.7860/JCDR/2015/14681.6692 
16. Ahmed T, Baidya S, Acharjee M, Rahman T. Qualitative analysis of drinking water through the most probable number (MPN) method. Stamford J Microbiol 2013; 3(1): 9-16. https://doi.org/10.3329/sjm.v3i1.22745

17. Nazemi S, Mirzaii M, Yaslianifard S, Sarokhalil D, Khoramrooz S, Norozi P, Davardoost F. Microbiological qualification of air, water and dialysate in a haemodialysis center: a new focus on Legionella spp. Iranian $\mathbf{J}$ microbiol 2016; 8(4): 219-225.PMID: 28210459

18. Bauer A, Kirby W, Sherris J, Turch A. Antibiotic susceptibility testing by standardized single disk method. American J Clin Path 1966; .45(4): 493- 496. https://doi.org/10.1086/313788

19. Pisani B, Simoes M, Prandi M, Rocha M, Goncalves C, Vaz T,Irino K. Outbreak of Pseudomonas aeruginosa bacteremia in a Hemodialysis Center in Campinas, São Paulo, Brazil. A Revista do Instituto Adolfo Lutz 2000;59(1/2): 51-56. https://doi.org/10.1590/S0036-46652009000100007

20. Lima J, Marques S, Gonçalves A, Filho N, Nunes P, Silva H, Monteiro S,Costa J. Microbiological analyses of water from hemodialysis services in Sao Luis, Maranhao, Brazil. Brazilian J Microbiol 2005; 36(2):103-108.

21. Arvanitidou M, Vayona A, Spanaki N, Tsakris A. Occurrence and antimicrobial resistance of Gram negative bacteria isolated in hemodialysis water and dialysate of renal units: result of a Greek multicentre study. J Applied Microbiol 2003; 95: 180- 185 https://doi.org/10.1046/j.1365-2672.2003.01966.x

22. Borges C, Lascowski K, Filho N, Pelayo J. Microbiological quantity of water and dialysate in a haemodialysis unit in
Ponta Grossa-PR. Brazil. JApp Microbiol 2007; 103:17911797 .https://doi.org/10.1111/j.1365-2672.2007.03431.x

23. Vanholder R, Vanhaecke E, Ringoir S. Waterborne Pseudomonas septicemia. American Soc Artif Int Organs Trans 1990; 36(3): 215-218.

24. Nystrand R. Thoughts about biofilm in dialysis water systems. EDTNA/ERCA J 2003; 29(3):127-30. https://doi.org/10.1111/j.1755-6686.2003.tb00292.x

25. Berns JS, Tokars JI. Preventing bacterial infections and antimicrobial resistance in dialysis patients. Am J Kidney Dis 2002; 40(5): 886-898. https://doi.org/10.1053/ajkd.2002.36332

26. Romanus I, Emmanuel N, et al. Antibiotic susceptibility patterns of bacterial isolates from hospitalized patients in Abakaliki. Int Res J Basic Clin Stud 2013; 1(4): 46-52. https://doi.org/10.1155/2018/8492309

27. Omoya F, Ajayi K. Antibiotic resistance pattern of pathogenic bacteria isolated from poultry droppings in Akure, Nigeria. Futa J Res Sci2016; 12 (2): 219 -227.

28. Yah S, Eghafona N, Oranusi S, Abouo A. Widespread plasmid resistance genes among Proteus species in diabetic wounds of patients in the Ahmadu Bello University teaching hospital (ABUTH) Zaria. African J Biotech 2007; 6 (15): 1757-1762

29. Khan S, Feroz F, Noor R. Study of extended-spectrum blactamase-producing bacteria from urinary tract infections in Bangladesh. Tzu Chi Medical J 2013; 25: 39- 42. https://doi.org/10.1016/j.tcmj.2013.01.008 